\title{
Germination of Medicago sativa is inhibited by soluble compounds in cement dust
}

\author{
Cristina Lafragüeta ${ }^{1}$, Balbino García-Criado ${ }^{1}$, Angel Arranz ${ }^{2}$, \\ Beatriz R. Vázquez-de-Aldana ${ }^{{ }^{*}}$
}

1. Instituto de Recursos Naturales y Agrobiología de Salamanca; Consejo Superior de Investigaciones Cientificas (IRNASA-CSIC);

Cordel de Merinas 40-52; 37008 Salamanca; Spain

2. Grupo Inzamac; 49024 Zamora; Spain

*Corresponding author:

Beatriz R. Vázquez-de-Aldana

Email: beatriz.dealdana@irnasa.csic.es

Phone: +34923219606

Fax: +34 923219609

"This is a post-peer-review, pre-copyedit version of an article published in Environmental Science and Pollution Research. The final authenticated version is available online at: http:// dx.doi.org/10261/181250". 


\begin{abstract}
Deposition of cement dust on soils and plant surfaces is known to affect plant growth and the species composition of plant communities, but little is known about its effects (and those of its $\mathrm{pH}$ and constituents) on germination. Therefore, the aim of this study was to assess the toxicity of an aqueous cement extract, constituents of the extract and $\mathrm{pH}$ on the germination of seeds of a selected species, Medicago sativa. First, the effects of the extract were tested in assays with concentrations and exposure durations ranging from 0 to $1.0 \mathrm{~g} / \mathrm{mL}$ and 4 to $96 \mathrm{~h}$, respectively. At $0.8 \mathrm{~g} / \mathrm{mL}$ the extract strongly inhibited germination; a $4 \mathrm{~h}$ exposure reduced the germination rate, from $77 \pm 1.8 \%$ to $50 \pm$ $2.6 \%$ (mean $\pm \mathrm{SE}$ ) while $8 \mathrm{~h}$ exposure completely inhibited it. Further, treatment at this concentration killed the non-germinating seeds, thus the inhibition was due to toxic effects. Neither the $\mathrm{pH}$ of the extract nor the concentration of its main soluble elements separately $(\mathrm{K}, \mathrm{Ca}, \mathrm{S}, \mathrm{Na}$ or $\mathrm{Cr}$ ) caused the toxicity, since germination rates were not significantly reduced when these variables were tested individually. However, a mixture of the elements in solution reduced germination rates, suggesting that they have adverse synergistic effects.
\end{abstract}

Keywords seed germination; alfalfa; toxicity; cement extracts; elemental composition

\title{
Introduction
}

Cement is a finely ground mixture of clinker (nodules formed by sintering limestone and clay or shale), small proportions of gypsum (usually) and sometimes smaller proportions ( $\leq 1 \%$; EN 2011) of additives such as fly ash or blast furnace slag. Thus, it is mainly composed of calcium, silicon and aluminium oxides $\left(\mathrm{CaO}, \mathrm{SiO}_{2}\right.$ and $\left.\mathrm{Al}_{2} \mathrm{O}_{3}\right)$ with minor proportions of elements such as sulphur, sodium and potassium, and traces of other elements at concentrations that largely depend on the additives.

Due to its chemical composition and fine size, cement dust is strongly alkaline, it is a common air pollutant and its deposition may strongly affect both plant growth and the species composition of plant communities around cement factories (Shukla et al. 1990; Farmer 1993; Hegazy 1996; Lukjanova and Mandre 2010; Fakhry and Migahid 2011). Persistent deposition of cement dust on the surface of leaves can adversely affect plants by blocking light and stomata, thereby reducing their photosynthetic rates and contents of chlorophyll, starch, carbohydrates, proteins and amino acid (Murugesan et al. 2004). It may also result in necrosis of leaves at distances up to $5 \mathrm{~km}$ from the emission source (Kumar et al. 2008; Rafiq et al. 2011). The overall effects on plant yield may be negligible in some cases (Gupta and Sharma 2011), but in the presence of moisture the cement dust may solidify into a hard adherent crust, which can damage plant tissues and severely inhibit growth (see Rafiq et al. 2011). 
In addition to these direct effects, cement dust may have potent indirect effects, via its accumulation in soil and the subsequent uptake of soluble components by plants. Important effects of its accumulation in soil include increases in soil $\mathrm{pH}$, which may reduce rates of photosynthesis, respiration, transpiration, cation uptake and growth (Singh 1983; Farmer 1993; Sharifi et al. 1997; Ots et al. 2011; Otts and Mandre 2012). In addition, as the pH ranges of plant species vary widely, the alkalization may strongly affect the composition of plant communities (Paal et al. 2012). Further, the deposition of cement dust in soils can raise levels of various ions, which may either reduce plant growth (Stravinskiene 2011), or (due to increases in levels of nutrients such as $\mathrm{Ca}, \mathrm{K}$, and $\mathrm{Mg}$ ) increase it, if the deposition is not excessive (Bayhan et al. 2002; Rai et al. 2003; Uysal et al. 2012).

Furthermore, germinable seed banks in soils may be reduced close to a cement dust pollution source (Hegazy 1996), and spraying moist (but not dry) cement dust on Vicia faba seeds reportedly inhibits their germination (Uysal et al. 2012). However, despite the importance of the effects of cement dust on plants, there is very little other information regarding its effects on seed germination, a key process in plant establishment. Therefore, the objective of the study presented here was to assess the effects of an aqueous cement extract, its high $\mathrm{pH}$ and its main soluble constituents on the germination of alfalfa (Medicago sativa) seeds. Alfalfa was selected because it is the main perennial forage legume in the Mediterranean basin and one of the most widely-grown crops in the world, being cultivated in countries ranging from Finland to South Africa (Barnes and Sheaffer 1985). It is also widely used as a cover crop to reduce soil erosion in nutrient-poor environments, due to its tolerance of low nutrient levels and other stresses (Bouton 2012).

\section{Materials and Methods}

Alfalfa seeds were purchased from Semillas Silvestres S.L. The cement dust used in all the germination assays was La Robla CEM II/A-V 42.5R cement, but for comparative purposes the chemical composition of both this and two other kinds of cement (Tudela-Veguin CEM II/B-V 32.5R and Portland-Valderrivas CEM IV/B-V 32.5N) were analysed by inductively coupled plasma atomic emission spectroscopy (names according to EN 197-1: 2011; hereafter La Robla, T-V and P-V, respectively, for convenience).

\section{Effect of aqueous cement extracts on germination}

Extracts of the La Robla cement dust were prepared at four concentrations $(0.3,0.6,0.8$ and $1.0 \mathrm{~g} / \mathrm{mL}$ ) by suspending corresponding amounts in deionized water and stirring for 10 minutes. To avoid a slow filtering due to filter obstruction with cement dust particles, the resulting suspensions were left to stand for 30 minutes then the aqueous phases were collected and filtered through FilterLab 1240 quantitative filter paper. Sets of 20 randomly chosen seeds were then placed on discs of germination paper (FilterLab, Barcelona, Spain) in $9 \mathrm{~cm}$ Petri dishes (105 in total). Triplicate sets were then exposed to the extracts, or water for controls, for $0,4,8,12,24,48,72$ or $96 \mathrm{~h}$ (in all 
permutations of concentrations and exposure durations), by soaking the paper discs with $5 \mathrm{~mL}$ portions of the appropriate extract or water then randomly placing the Petri dishes in a thermostatically controlled growth chamber $\left(12 \mathrm{~h}\right.$ light $/ 24{ }^{\circ} \mathrm{C} / 80 \%$ humidity and $12 \mathrm{~h}$ darkness/18 ${ }^{\circ} \mathrm{C} / 60 \%$ humidity cycles) at the beginning of the dark phase. After the allotted exposure durations, the dishes were removed, the numbers of germinated and ungerminated seeds were counted and the seeds they contained (both germinated and ungerminated, defining germination as protrusion of the radicle) were transferred to new dishes with freshwater-soaked paper disks. They were then incubated in the climate chamber under the same conditions and the numbers of seeds that germinated were counted daily for 9 days (when germination had ceased).

After 9 days, seeds that had been exposed to $0.8 \mathrm{~g} / \mathrm{mL}$ or $1.0 \mathrm{~g} / \mathrm{mL}$ cement dust and had not germinated were subjected to the tetrazolium test to determine whether or not they were still viable, following AOSA (2000). Briefly, the seeds were imbibed in water for $24 \mathrm{~h}$, cut in half longitudinally then placed in $1 \%$ tetrazolium triphenyl chloride solution (Scharlab) and incubated at $35{ }^{\circ} \mathrm{C}$ in the dark for 6-8 $\mathrm{h}$. Viable cells reduce tetrazolium to the product 1,3,5-triphenylformazan and hence are stained red, whilst dead cells remain unstained. Based on this staining we were able to record the number of live and dead seeds.

\section{Effects of $\mathrm{pH}$}

The effects of varying the $\mathrm{pH}$ of the cement extracts on the seeds' germination rates were tested as follows. An aqueous extract of the La Robla cement dust was prepared by suspending $25 \mathrm{~g}$ in $1 \mathrm{~L}$ of deionized water and stirring for 10 minutes. The suspension was left to stand for 30 minutes then filtered through FilterLab 1240 quantitative filter paper. The $\mathrm{pH}$ of the resulting solution was 12.9; another solution was obtained by adding $0.1 \mathrm{M} \mathrm{HCl}$ to $\mathrm{pH} 8.5$. Triplicate sets of 20 alfalfa seeds were then exposed to each of these solutions, or deionized water ( $\mathrm{pH}$ 6.9) for controls, and their germination rates were recorded as described above. In addition, to test the effects solely of more precisely controlled $\mathrm{pH}$ on germination, in the absence of the cement, in another assay sets of seeds were exposed to solutions of $2 \mathrm{mM}$ tricine [ $N$-tris(hydroxymethyl) methylglycine] adjusted with 1 $\mathrm{mM} \mathrm{NaOH}$ to $\mathrm{pH} 10.0,11.0$ and 12.9, again as described above.

\section{Chemical analysis}

The elemental contents of aqueous extracts of the cement were analysed by inductively coupled plasma atomic emission spectroscopy at the Servicio General de Análisis Aplicado, University of Salamanca (Salamanca, Spain). As mentioned above, extracts of two other types of cement (T-V and P-V) were also analysed to compare their concentrations of soluble constituents.

\section{Effects of $\mathrm{Ca}, \mathrm{K}, \mathrm{Na}, \mathrm{S}$ and $\mathrm{Cr}$ on germination}


The effects of $\mathrm{Ca}, \mathrm{K}, \mathrm{Na}, \mathrm{S}$, and $\mathrm{Cr}$ on germination of the seeds, at similar concentrations to those measured in the La Robla cement extract (see above), were individually assayed by exposing sets of seeds to $\mathrm{Ca}\left(\mathrm{NO}_{3}\right)_{2} \cdot 4 \mathrm{H}_{2} \mathrm{O}(1.0$ and $2.0 \mathrm{~g} / \mathrm{L}), \mathrm{KCl}(2.0$ and $4.0 \mathrm{~g} / \mathrm{L}), \mathrm{NaCl}(0.2$ and $0.4 \mathrm{~g} / \mathrm{L})$, $\mathrm{K}_{2} \mathrm{SO}_{4}(1.2$ and $2.4 \mathrm{~g} / \mathrm{L})$, and $\mathrm{K}_{2} \mathrm{Cr}_{2} \mathrm{O}_{7}(0.5,1.0$ and $2.0 \mathrm{mg} / \mathrm{L})$ solutions, as in the germination assay described above. To test the additive effects of the elements a further germination assay was carried out with three solutions containing all the elements: M3, containing $2.0 \mathrm{~g} / \mathrm{L} \mathrm{Ca}, 5.8 \mathrm{~g} / \mathrm{L} \mathrm{K}, 0.4 \mathrm{~g} / \mathrm{L} \mathrm{Na}$, $2.4 \mathrm{~g} / \mathrm{L} \mathrm{S}$ and $2.0 \mathrm{mg} / \mathrm{L} \mathrm{Cr}$; M2 (a two-fold dilution of M3), and M1 (a four-fold dilution of M3). The assay was carried out as described above except that there were five replicates.

\section{Statistical analysis}

Data obtained from the assay of effects of aqueous cement extracts on germination were analyzed for each concentration separately to determine the effect of exposure duration on germination by one-way ANOVA. Between-treatment differences in germination rates in the assays of $\mathrm{pH}$ and constituent effects were also analysed by one-way ANOVA. The data were subjected to $\log 10$-transformation prior to ANOVA to meet normality and homogeneity of variance requirements, when necessary, and significant $(P<0.05)$ differences between means were identified using the LSD procedure. The IBM SPSS Statistics 19 software package was used for all the statistical analyses.

\section{RESULTS}

\section{Effects of aqueous cement extracts on germination}

The alfalfa seeds began to germinate two days after imbibition in the Petri dishes, when seeds under treatments with longer exposure durations were still in contact with the cement extract. At this point, $63 \pm 5.3 \%$ (mean $\pm \mathrm{SE}$ ) of the seeds under the control treatment had germinated, but the proportion rose to $78 \pm 3.5 \% 9$ days after they were placed in plates with water (Fig. 1). After $48 \mathrm{~h}$ exposure to the $0.3 \mathrm{~g} / \mathrm{mL}$ extract, $40 \pm 5.3 \%$ seeds had germinated, and $73 \pm 0.6 \% 7$ days after they were transferred to water (Fig. 1). Similar results were obtained for the $0.6 \mathrm{~g} / \mathrm{mL}$ treatment. Thus, exposure to the $0.3 \mathrm{~g} / \mathrm{mL}$ and $0.6 \mathrm{~g} / \mathrm{mL}$ extracts for $48 \mathrm{~h}$ non-lethally inhibited germination. However, seeds exposed to $0.8 \mathrm{~g} / \mathrm{mL}$ and $1.0 \mathrm{~g} / \mathrm{mL}$ extracts for $48 \mathrm{~h}$ did not germinate when they were transferred to fresh water, indicating that these treatments killed he seeds (Fig. 1). This was confirmed by the tetrazolium assay, since seeds remained colourless after the treatments (Fig. 3).

Furthermore, final germination rates did not vary with the duration of exposure to the cement extract among treatments with $0,0.3$ or $0.6 \mathrm{~g} / \mathrm{mL}$ extracts: they were consistently $67 \pm 2.0 \%$ to $87 \pm$ $2.1 \%$ under these treatments. However, exposure to the 0.8 and $1.0 \mathrm{~g} / \mathrm{mL}$ extracts dramatically reduced germination rates: after exposure to $0.8 \mathrm{~g} / \mathrm{mL}$ for $4 \mathrm{~h}$ and longer durations the rates fell to 50 $\pm 2.6 \%$, and $0-2 \%$, respectively (Fig. 2 ). 


\section{Effects of pH}

Germination of the seeds was not significantly affected by changing the $\mathrm{pH}$ of the unbuffered cement extract from the initial 12.9 to 8.5 using $\mathrm{HCl}$ (Fig. 4a), or to $10.0,11.0$ or 12.9 using $2 \mathrm{mM}$ tricine and $\mathrm{NaOH}$ (Fig. 4b).

\section{Chemical composition of the cement extracts}

Results of chemical analysis of the three aqueous cement extracts $(0.8 \mathrm{~g} / \mathrm{mL})$ are presented in Table 1. The main elemental constituents detected in the La Robla cement extract were K, S, Ca and $\mathrm{Na}(4108$ to $421 \mathrm{mg} / \mathrm{L})$ with substantially lower contents of $\mathrm{Fe}, \mathrm{Cr}$ and $\mathrm{Si}(14.8$ to $0.8 \mathrm{mg} / \mathrm{L})$. The main differences in composition between cements were found in $\mathrm{K}$ with greater concentration in $\mathrm{La}$ Robla than in the other two (T-V and P-V) (Table 1).

\section{Effects of mineral elements (K, Ca, S, Na and $\mathrm{Cr}$ )}

Germination of the seeds was not significantly affected by treatment with any of the individual $\mathrm{K}, \mathrm{Ca}, \mathrm{S}, \mathrm{Na}$ and $\mathrm{Cr}$ salt solutions, at any test concentration (Table 2). However, the mixture of salts with the highest concentrations (M3) reduced the rate from $76 \pm 1.6 \%$ to $25 \pm 8.3 \%$ (Table 3).

\section{DISCUSSION}

The results show that water-soluble constituents of cement dust inhibit the germination of alfalfa seeds and are highly toxic. Germination of the seeds was completely inhibited by exposure to the La Robla cement extract at $0.8 \mathrm{~g} / \mathrm{mL}$ for $8 \mathrm{~h}$, and the same treatment for $4 \mathrm{~h}$ approximately halved the germination rate. Thus, this is close to the EC50 (the effective concentration that reduces seed germination rates by $50 \%$ with $4 \mathrm{~h}$ exposure). The inhibition of seed germination at this concentration was not due to osmotic effects, since the seeds did not germinate when transferred to new dishes with fresh water, and the tetrazolium test confirmed that these ungerminated seeds were dead (Fig. 3). Thus, the inhibition was due to toxic effects of the cement extract. In contrast, the germination of seeds exposed to cement extracts at lower concentrations $(\leq 0.6 \mathrm{~g} / \mathrm{mL})$ was non-lethally inhibited, as the seeds germinated when they were transferred to fresh water. The concentrations of metallic elements detected in the $0.8 \mathrm{~g} / \mathrm{mL}$ extract were lower than those detected in cement-contaminated soils by Uysal et al. (2012). Thus, they may have stronger effects on seed germination than those we detected in at least some cement-contaminated environments.

One of the variables that can strongly affect seed germination is the pH (Pierce et al. 1999; Chachalis and Reddy 2000), and soil alkalinisation is one of the main factors affecting plant growth in areas contaminated with cement dust (Fakhry and Migahid 2011). The initial pH of the cement extract was 12.9 , and our assays with both buffered and unbuffered cement extracts showed that varying the 
$\mathrm{pH}$ between 8.5 and 12 did not have a significant effect on germination of the alfalfa seeds. However, the effects of $\mathrm{pH}$ on seed germination are highly dependent on the plant species; seeds of some species can germinate in media with a wide range of $\mathrm{pH}$ values (Nakamura and Hossain 2009), while others have a much narrower $\mathrm{pH}$ range and their germination may be strongly inhibited by $\mathrm{pH} \geq 7$. For instance the optimum $\mathrm{pH}$ for the germination of Erica australis is reportedly 4.0 (Vera et al. 2010). Thus, between-species differences in the effects of soil alkalization by cement dust may substantially contribute to its observed effects on the species composition of plant communities.

We initially hypothesized that the toxicity preventing germination of the alfalfa seeds was due to high concentrations of one or more inorganic elements in the cement extract. The chemical analysis of the aqueous extract showed that it contained high concentrations of $\mathrm{Ca}, \mathrm{K}, \mathrm{Na}$ and $\mathrm{S}$, and traces of $\mathrm{Cr}$ (Table 1); but none of these elements individually inhibited alfalfa germination at the concentrations found in the extract. The effect of salts on germination is mainly osmotic in some species, but salts may also have toxic effects on seeds (see Tobe et al. 2003). For species in which the seed coat is permeable to salts, moistening the seeds with saline solutions can cause loss of germinability. However, for other species, the embryo may be protected from salts by the seed coat before the seed germinates, and it is injured by salts only after it protrudes from the seed coat (Tobe et al. 1999).

Chrome can be highly toxic for plants, especially in the hexavalent form $\mathrm{Cr}(\mathrm{VI})$ (Hayat et al. 2012), $2 \mathrm{mg} / \mathrm{kg}$ dry matter reportedly being the critical leaf concentration for toxicity (White and Brown 2010). For example, concentrations of $\mathrm{Cr}$ of 2.35 to $14.1 \mathrm{mg} / \mathrm{L}$ reportedly non-lethally inhibit germination of Lolium perenne seeds (Chigbo and Batty 2013). This is substantially higher than the concentration detected in the aqueous cement extract used in our assays. Other elements such as $\mathrm{Ca}$ or $\mathrm{Na}$ can also prevent seed germination (Cai and Gao 2011), but only at higher concentrations than those detected in the cement extracts we used. Cement dust also contains several oxides including $\mathrm{Al}_{2} \mathrm{O}_{3}$ or $\mathrm{MnO}_{2}$ (EN 2011). However, most of these oxides are highly insoluble in water (and largely immobilized in cement), thus they would have been present at very low concentrations (ppb) in the cement aqueous extracts. This could explain why several elements, including $\mathrm{Al}$ or $\mathrm{Mn}$, were not be detected in the ICP analysis, and thus cannot account for the cement extract's toxicity.

We found that a mixture of the elements in solution significantly inhibited germination of the seeds; much more strongly than the elements individually, suggesting that synergistic effects of the elements (or ions) could at least partly explain the toxicity of the cement extracts. However, we used several salts to prepare our assay mixtures, containing anions that are probably not present in the cement extracts but may have contributed to the observed synergistic effect. Accordingly, synergistic effects of various substances (organic and inorganic) on the germination of seeds of several plant species have been previously detected (Chen et al. 2010; Hadi et al. 2010; Yao et al. 2010). A substance used as an additive could also have contributed to the toxicity of the cement extracts. However, European regulations set maximum contents of inorganic and organic additives in cement at 
$1 \%$ and $0.5 \%(\mathrm{w} / \mathrm{w})$, respectively (EN 2011). Hence, their concentrations in cement extracts are very low.

The main conclusion is that the toxic effects of the aqueous cement extracts on alfalfa seed germination were not caused by any particular inorganic element, but could be due to interactive effects of inorganic constituents and/or inorganic additives. Thus, the results indicate that, as well as reducing photosynthetic rates by forming barriers on leaf surfaces, dust originating from cement factories may strongly, and potentially lethally, inhibit seed germination in the presence of moisture.

\section{Acknowledgements}

This work was supported by a research contract with Grupo Inzamac, San Gregorio (Construcciones) and Collosa companies through a project supported by ADE (Agencia de Desarrollo Económico of the regional Junta de Castilla y León) and FEDER (Fondo Europeo de Desarrollo Regional). Cristina Lafragüeta's contribution was funded by this contract. Thanks are also due to Emilio Romero (University of Salamanca, Spain) and Dr. Pedro Gundel (University of Buenos Aires, Argentina) for helpful comments on the chemical analysis of cement and the manuscript, respectively.

\section{References}

Association of Official Seed Analysts (AOSA), Tetrazolium Subcommittee (2000) Tetrazolium Testing Handbook. Contribution $\mathrm{N}^{\mathrm{o}} 29$ to the Handbook on Seed Testing. Jack Peters (ed)

Barnes DK, Sheaffer CC (1985) Alfalfa. In: Heath ME, Barnes RF, Metcalfe DS (eds) Forages. The Science of Grassland Agriculture, $4^{\text {th }}$ edn. Iowa State University Press, Iowa, pp 89-97

Bayhan YK, Yapici S, Kocaman B., Nuhoglu A, Cakici A (2002) The effect of cement dust on some soil characteristics. Fresenius Environ Bull 11: 1030-1033

Bouton JH (2012) An overview of the role of lucerne (Medicago sativa L.) in pastoral agriculture. Crop Pasture Sci 63:734-738

Cai H, Gao D (2011) Phytotoxicity of salts in composted sewage sludge and correlation with sodium chloride, calcium nitrate, and magnesium nitrate. J Plant Nut 34:1788-1796

Chachalis D, Reddy KN (2000) Factors affecting Campsis radicans seed germination and seedling emergence. Weed Sci 48:212-216

Chen C, Zhou Q, Bao Y, Li Y, Wang P (2010) Ecotoxicological effects of polycyclic musks and cadmium on seed germination and seedling growth of wheat (Triticum aestivum). J Environ Sci 22:1966-1973

Chigbo C, Batty L (2013) Effect of combined pollution of chromium and benzo (a) pyrene on seed growth of Lolium perenne. Chemosphere 90:164-169

European Normative EN 197-1:2011 (2011) Cement. Part 1: Composition, specifications and conformity criteria for common cements 
Fakhry AM, Migahid MM (2011) Effect of cement-kiln dust pollution on the vegetation in the western Mediterranean desert of Egypt. World Academy Sci Engineer Technol 81:28-34

Farmer AM (1993) The effects of dust on vegetation - a review. Environ Pollut 79:63-75

Gupta S, Sharma S (2011) Effect of calcium, magnesium and lead in cement dust in Charkara village of Nokha (Bikaner). Int J Chem Sci 9:1913-1919

Hadi F, Bano A, Fuller MP (2010) The improved phytoextraction of lead $(\mathrm{Pb})$ and the growth of maize (Zea mays L.): The role of plant growth regulators (GA 3 and IAA) and EDTA alone and in combinations. Chemosphere 80:457-462

Hayat S, Khalique G, Irfan M, Wani AS, Tripathi BN, Ahmad A (2012) Physiological changes induced by chromium stress in plants: An overview. Protoplasma 249:599-611

Hegazy AK (1996) Effects of cement-kiln dust pollution on the vegetation and seed-bank species diversity in the eastern desert of Egypt. Environ Conserv 23:249-258

Kumar SS, Singh NA, Kumar V, Sunisha B, Preeti S, Deepali S, Nath SR (2008) Impact of dust emission on plant vegetation in the vicinity of cement plant. Environ Engineer Manag J 7:3135

Lukjanova A, Mandre M (2010) Effects of alkalization of the environment on the anatomy of Scots pine (Pinus sylvestris) needles. Water Air Soil Pollut 206:13-22

Murugesan M, Sivakumar A, Jayanthi N, Manonmani K (2004) Effect of cement dust pollution on physiological and biochemical activities of certain plants. Pollut Res 23:375-378

Nakamura I, Hossain MA (2009) Factors affecting the seed germination and seedling emergence of redflower ragleaf (Crassocephalum crepidioides). Weed Biol Manag 9:315-322

Ots K, Indriksons A, Varnagiryte-Kabasinskiene I, Mandre M, Kuznetsova T, Klõšeiko J, Tilk M, Kõresaar K, Lukjanova A, Kikamägi K (2011) Changes in the canopies of Pinus sylvestris and Picea abies under alkaline dust impact in the industrial region of Northeast Estonia. Forest Ecol Manag 262:82-87

Ots K, Mandre M (2012) Monitoring of heavy metals uptake and allocation in Pinus sylvestris organs in alkalised soil. Environ Monit Assessm 184:4105-4117

Paal J, Degtjarenko P, Suija A, Liira J (2012) Vegetation responses to long-term alkaline cement dust pollution in Pinus sylvestris-dominated boreal forests - niche breadth along the soil $\mathrm{pH}$ gradient. Appl Veg Sci Doi:10.1111/j.1654-109X.2012.01224.x

Pierce GL, Warren SL, Mikkelsen RL, Linker HM (1999) Effects of soil calcium and pH on seed germination and subsequent growth of large crabgrass (Digitaria sanguinalis). Weed Technol $13: 421-424$

Rai UN, Gupta DK, Akhtar M, Pal A (2003) Performance of seed germination and growth of Vicia faba L. in fly ash amended soil. J Environ Biol 24: 9-15

Rafiq SK, Khalid S, Sheikh BA, Khan NA, Paul MI (2011) Impact of cement dust on growth and metabolism of Brassica olekeacea. Pollut Res 30:107-111 
Sharifi MR, Gibson AC, Rundel PW (1997) Surface dust impacts on gas exchange in Mojave Desert shrubs. J Appl Ecol 34:837-846

Shukla J, Pandey V, Singh SN, Yunus M, Singh N, Ahmad KJ (1990) Effect of cement dust on the growth and yield of Brassica campestris L. Environ Pollut 66:81-88

Singh SN (1983) Alternation of mineral accumulation pattern of Triticum aestivum L. exposed to particulate pollution. Environ Pollut Series A: Ecol Biol 32:171-177

Stravinskiene V (2011) Pollution of Akmenes cementas vicinity: Alkalizing microelements in soil, composition of vegetation species and projection coverage. J Environ Engineer Landsc Manag 19:130-139

Tobe K, Zhang L, Omasa K (1999) Effects of $\mathrm{NaCl}$ on seed germination of five nonhalophytic species from a Chinese desert environment. Seed Sci Technol 27:851-863

Tobe K, Zhang L, Omasa K (2003) Alleviatory effects of calcium on the toxicity of sodium, potassium and magnesium chlorides to seed germination in three non-halophytes. Seed Sci Res 13:47-54

Uysal I, Özdilek HG, Öztürk M (2012) Effect of kiln dust from a cement factory on growth of Vicia faba L. J Environ Biol 33:525-530

Vera DT, Martín RP, Oliva SR (2010) Effect of chemical and physical treatments on seed germination of Erica australis. Annales Botanici Fennici 47:353-360

White PJ, Brown PH (2010) Plant nutrition for sustainable development and global health. Ann Bot 105:1073-1080

Yao S, Chen S, Zhao J, Xu D, Lan H, Zhang F (2010) Effect of three salts on germination and seedling survival of dimorphic seeds of Chenopodium album. Botany 88:821-828 
Table 1 Elemental analysis of an $0.8 \mathrm{~g} / \mathrm{mL}$ aqueous cement extract. Three types of cement were analysed, La Robla was the cement used for the assays. Elemental concentrations in $\mathrm{mg} / \mathrm{L}$

\begin{tabular}{cccc}
\hline Element & $\begin{array}{c}\text { La Robla } \\
\text { CEM II/A-V 42.5R }\end{array}$ & $\begin{array}{c}\text { Tudela-Veguin } \\
\text { CEM II/B-V 32.5R }\end{array}$ & $\begin{array}{c}\text { Portland-Valderrivas } \\
\text { CEM IV/B-V 32.5N }\end{array}$ \\
\hline $\mathrm{K}$ & 4108 & 3286 & 2882 \\
$\mathrm{Ca}$ & 2027 & 2632 & 2452 \\
$\mathrm{~S}$ & 2437 & 2422 & 2598 \\
$\mathrm{Na}$ & 421 & 618 & 336 \\
$\mathrm{Fe}$ & 14.8 & 22.0 & 22.4 \\
$\mathrm{Cr}$ & 2.0 & 2.2 & 2.4 \\
$\mathrm{Si}$ & 0.8 & 0.2 & 0.6 \\
\hline
\end{tabular}


Table 2 Effects of $\mathrm{Ca}, \mathrm{K}, \mathrm{Na} \mathrm{S}$ and $\mathrm{Cr}$ (in aqueous solution) on germination rates of Medicago sativa seeds. $P$ values for each element are from one-way ANOVA of the effects of its concentration

\begin{tabular}{|c|c|c|c|c|}
\hline \multirow{2}{*}{ Element } & \multirow{2}{*}{$\begin{array}{c}\text { Concentration } \\
(\mathrm{g} / \mathrm{L})\end{array}$} & \multicolumn{2}{|c|}{ Germination rate $(\%)$} & \multirow{2}{*}{$P$} \\
\hline & & mean & SE & \\
\hline \multirow[t]{3}{*}{$\mathrm{Ca}$} & 0 & 82 & 2.9 & \multirow[t]{3}{*}{0.763} \\
\hline & 1.0 & 70 & 5.8 & \\
\hline & 2.0 & 77 & 9.3 & \\
\hline \multirow[t]{3}{*}{ K } & 0 & 82 & 2.9 & \multirow[t]{3}{*}{0.800} \\
\hline & 2.0 & 82 & 1.7 & \\
\hline & 4.0 & 77 & 12.0 & \\
\hline \multirow[t]{3}{*}{$\mathrm{Na}$} & 0 & 82 & 2.9 & \multirow[t]{3}{*}{0.287} \\
\hline & 0.20 & 83 & 6.7 & \\
\hline & 0.40 & 73 & 1.7 & \\
\hline \multirow[t]{3}{*}{ S } & 0 & 82 & 2.9 & \multirow[t]{3}{*}{0.298} \\
\hline & 1.2 & 77 & 10.9 & \\
\hline & 2.4 & 90 & 2.9 & \\
\hline \multirow{4}{*}{$\mathrm{Cr}$} & 0 & 82 & 2.9 & \multirow{4}{*}{0.754} \\
\hline & $0.510^{-3}$ & 78 & 7.2 & \\
\hline & $1.010^{-3}$ & 82 & 9.3 & \\
\hline & $2.010^{-3}$ & 75 & 5.0 & \\
\hline
\end{tabular}


Table 3 Effects on germination of Medicago sativa seeds of three solutions containing a mixture of $\mathrm{Ca}\left(\mathrm{NO}_{3}\right)_{2} \cdot 4 \mathrm{H}_{2} \mathrm{O}, \mathrm{NaCl}, \mathrm{K}_{2} \mathrm{SO}_{4}$ and $\mathrm{K}_{2} \mathrm{Cr}_{2} \mathrm{O}_{7}$ : M3, containing $2.0 \mathrm{~g} / \mathrm{L} \mathrm{Ca}, 5.8 \mathrm{~g} / \mathrm{L} \mathrm{K}, 0.4 \mathrm{~g} / \mathrm{L} \mathrm{Na}, 2.4 \mathrm{~g} / \mathrm{L}$ $\mathrm{S}$ and $2.0 \mathrm{mg} / \mathrm{L} \mathrm{Cr}$; M2, a 1:1 dilution of concentration of M3; and M1, a 1:3 dilution of M3

\begin{tabular}{cccc}
\hline & \multicolumn{2}{c}{ Germination rate (\%) } & \multirow{2}{*}{$P$} \\
\cline { 2 - 3 } & mean & SE & \\
\hline & & & \\
Control & 76 & 1.6 & 0.012 \\
M1 & 62 & 8.3 & \\
M2 & 53 & 4.1 & \\
M3 & 25 & 8.3 & \\
\hline
\end{tabular}


Fig. 1 Time-courses of germination rates of Medicago sativa seeds after transfer to fresh water after $48 \mathrm{~h}$ treatment with aqueous cement extract at indicated concentrations $(0 ; 0.3 ; 0.6 ; 0.8 ; 1.0 \mathrm{~g} / \mathrm{mL})$. Values are means $\pm \mathrm{SE}(\mathrm{n}=3)$. For each concentration, different letters indicate significant differences at $P<0.05$ according to the LSD test

Fig. 2 Effects of an aqueous cement extract at indicated concentrations $(0.3 ; 0.6 ; 0.8 ; 1.0 \mathrm{~g} / \mathrm{mL})$ and exposure durations $(4,8,12,24,48,72,96 \mathrm{~h})$ on the germination of Medicago sativa seeds. After exposure to the cement extract, seeds were transferred to dishes with fresh water. Values are germination rates (means $\pm \mathrm{SE}, \mathrm{n}=3$ ) at the end of the experiment ( 9 days after transfer), when germination had ceased

Fig. 3 Illustrative results of the tetrazolium seed viability test. Active enzymes in living cells reduce the colourless tetrazolium to a red, water-insoluble compound. Hence, living cells are stained red while dead cells remain colourless. In our study, treating seeds with 0.8 and $1.0 \mathrm{~g} / \mathrm{mL}$ cement extracts was lethal

Fig. 4 Effects of $\mathrm{pH}$ on the germination of Medicago sativa seeds: a) in an aqueous extract of cement with $\mathrm{HCl}$-modified $\mathrm{pH}$; b) in tricine-buffered solution. Values are means $+\mathrm{SE}(\mathrm{n}=3)$. Different letters indicate significant differences at $P<0.05$ according to the LSD test 


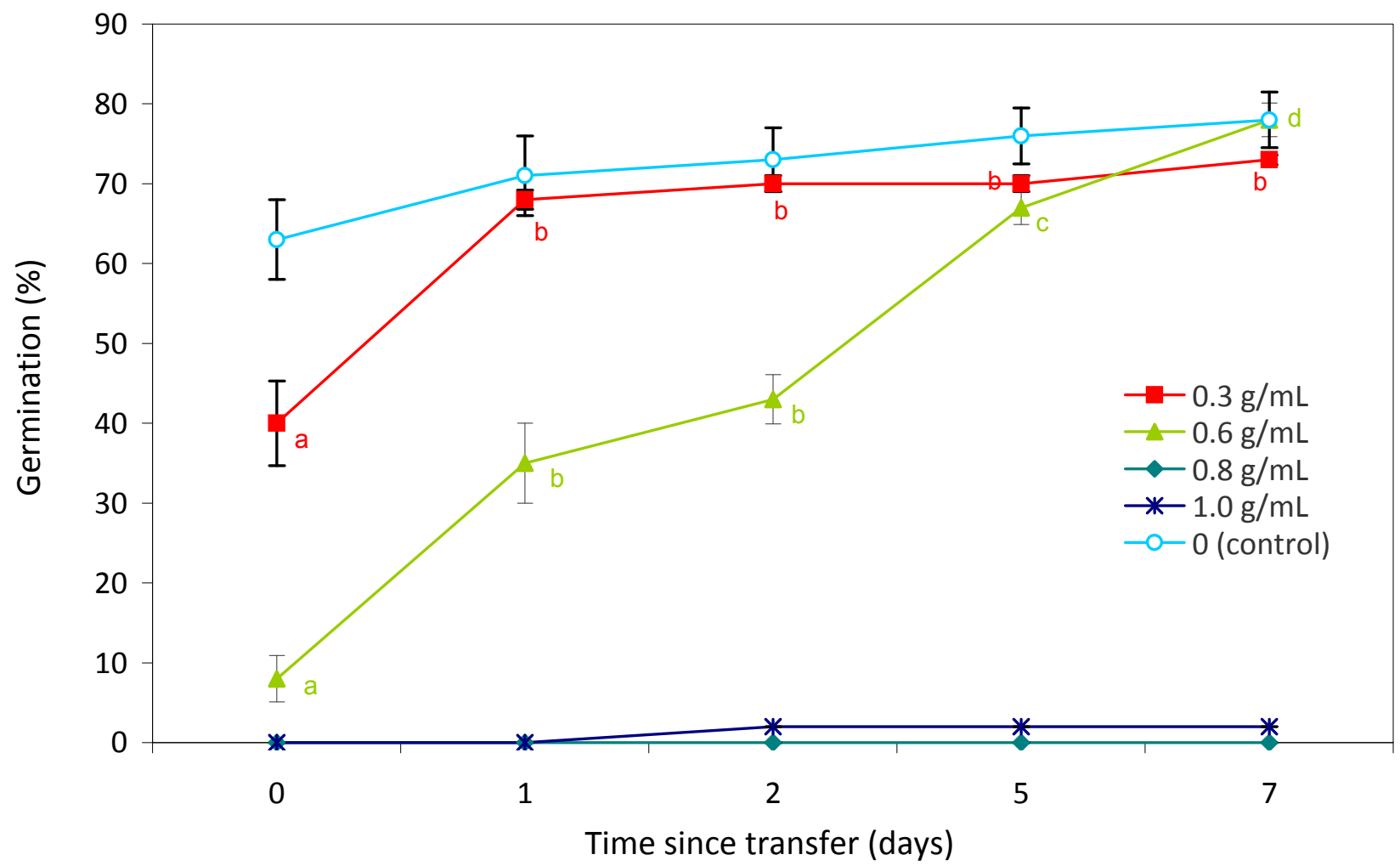




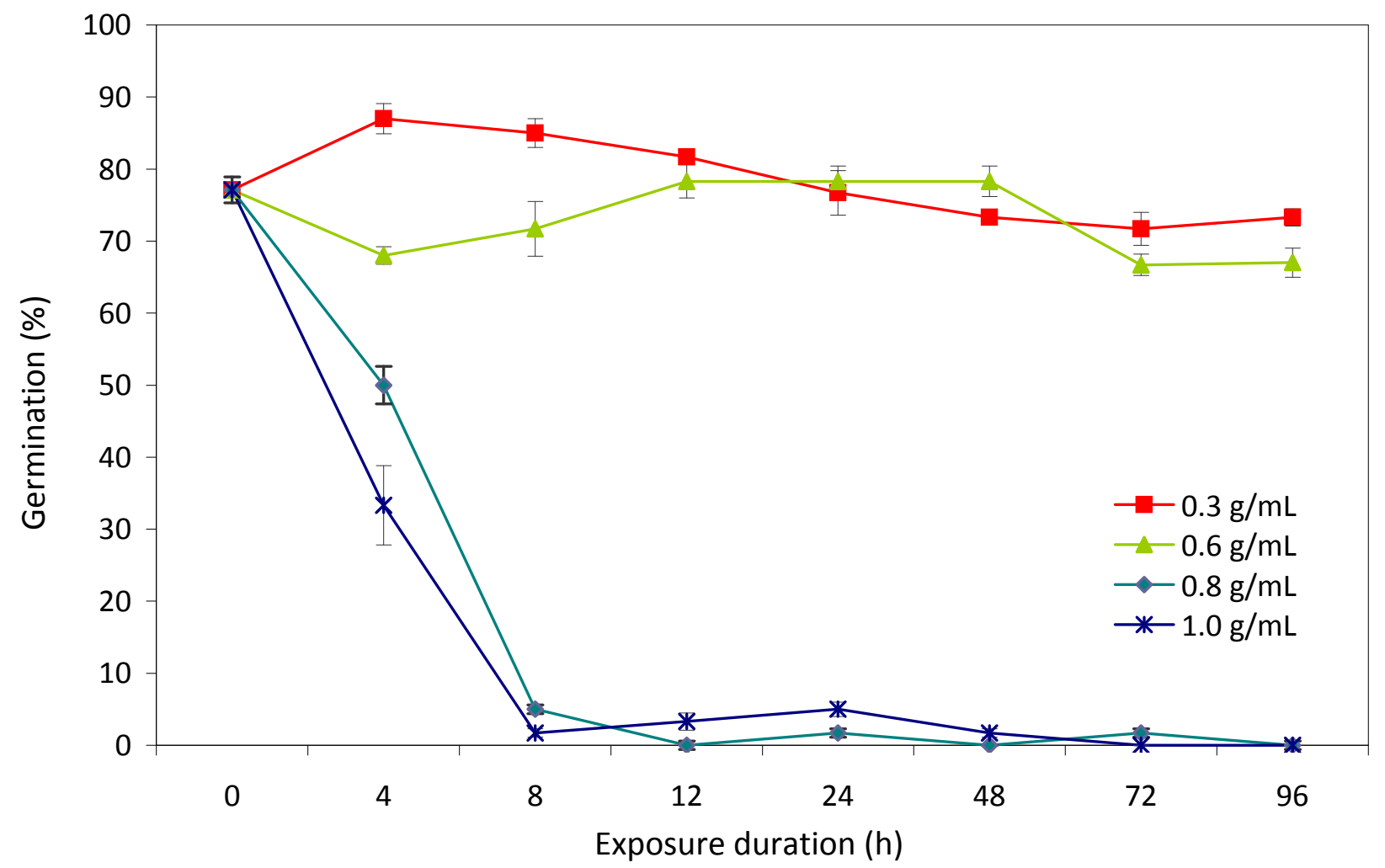




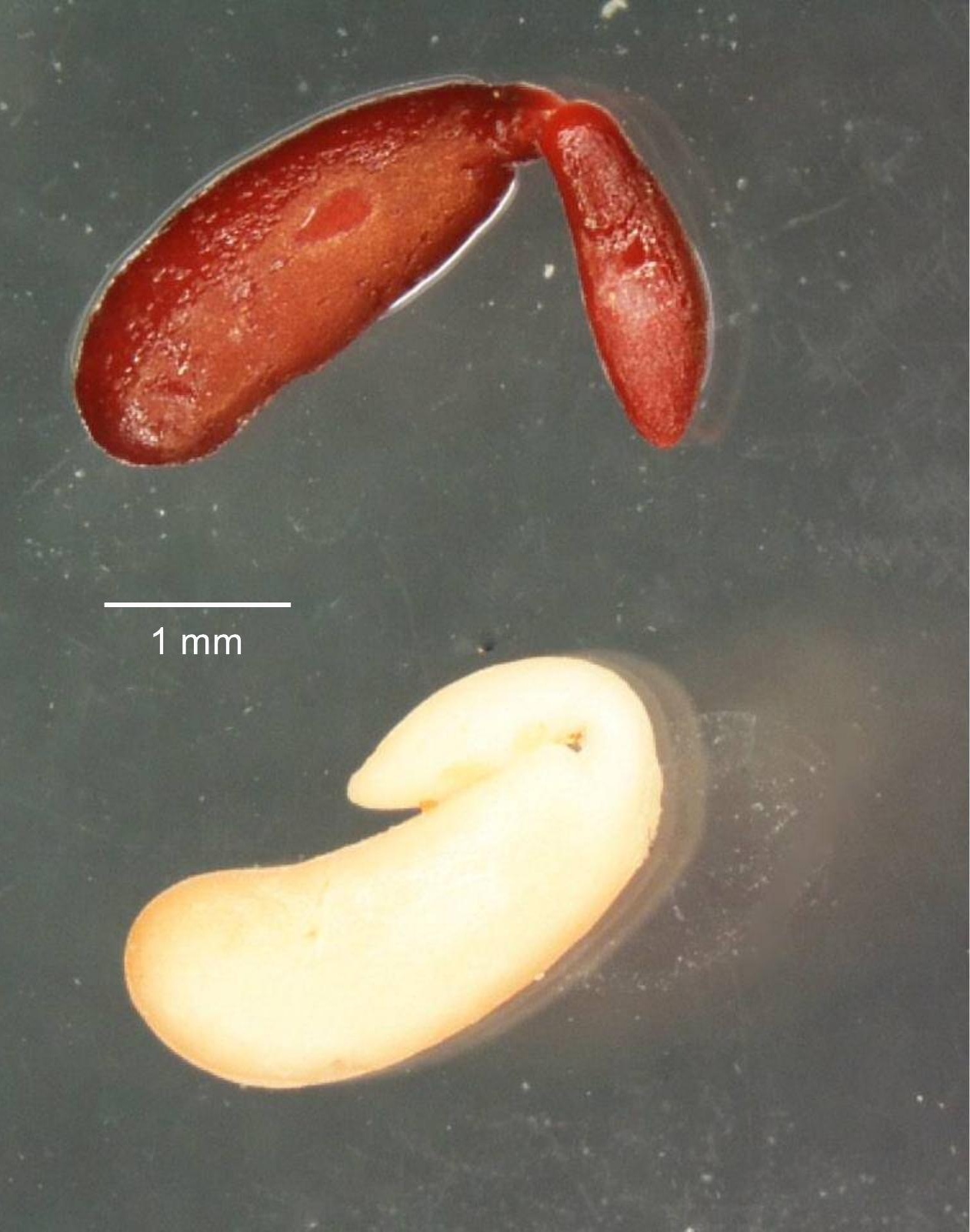


a

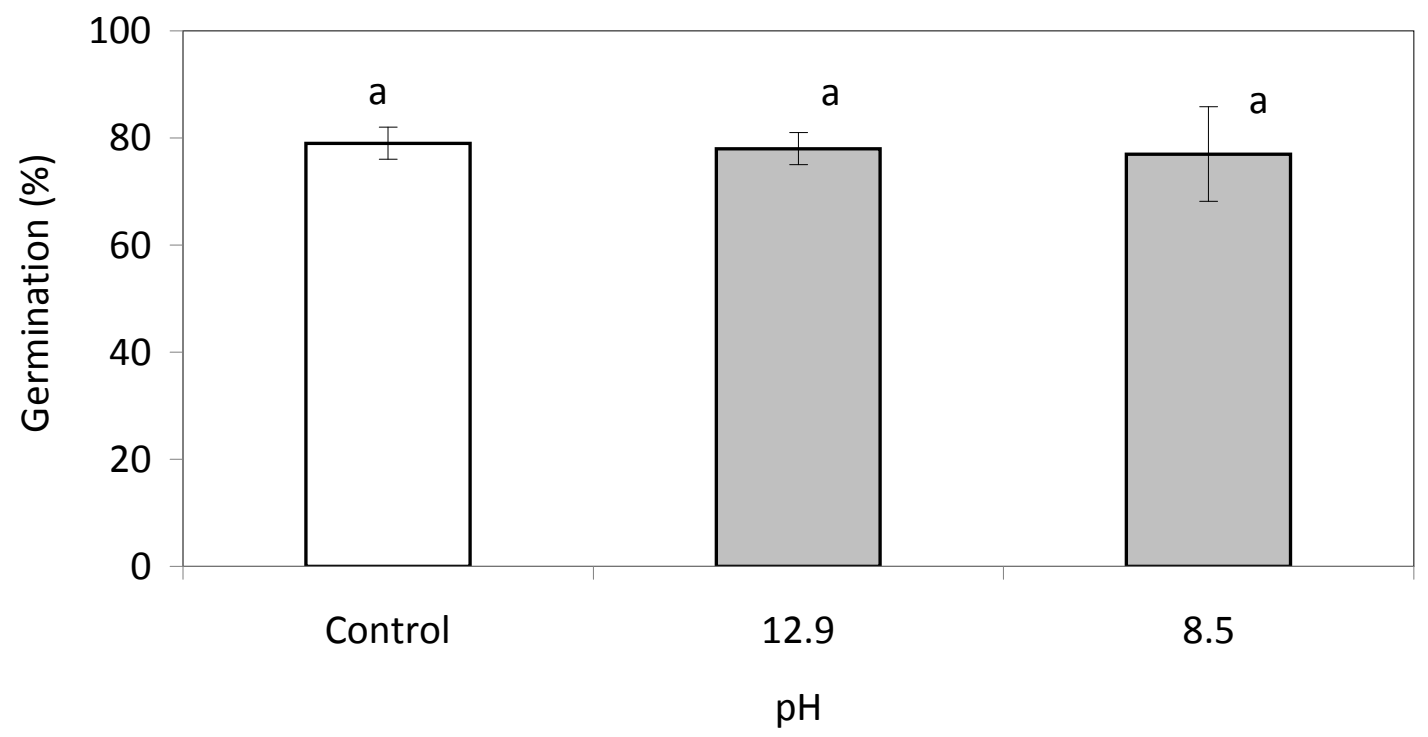

b

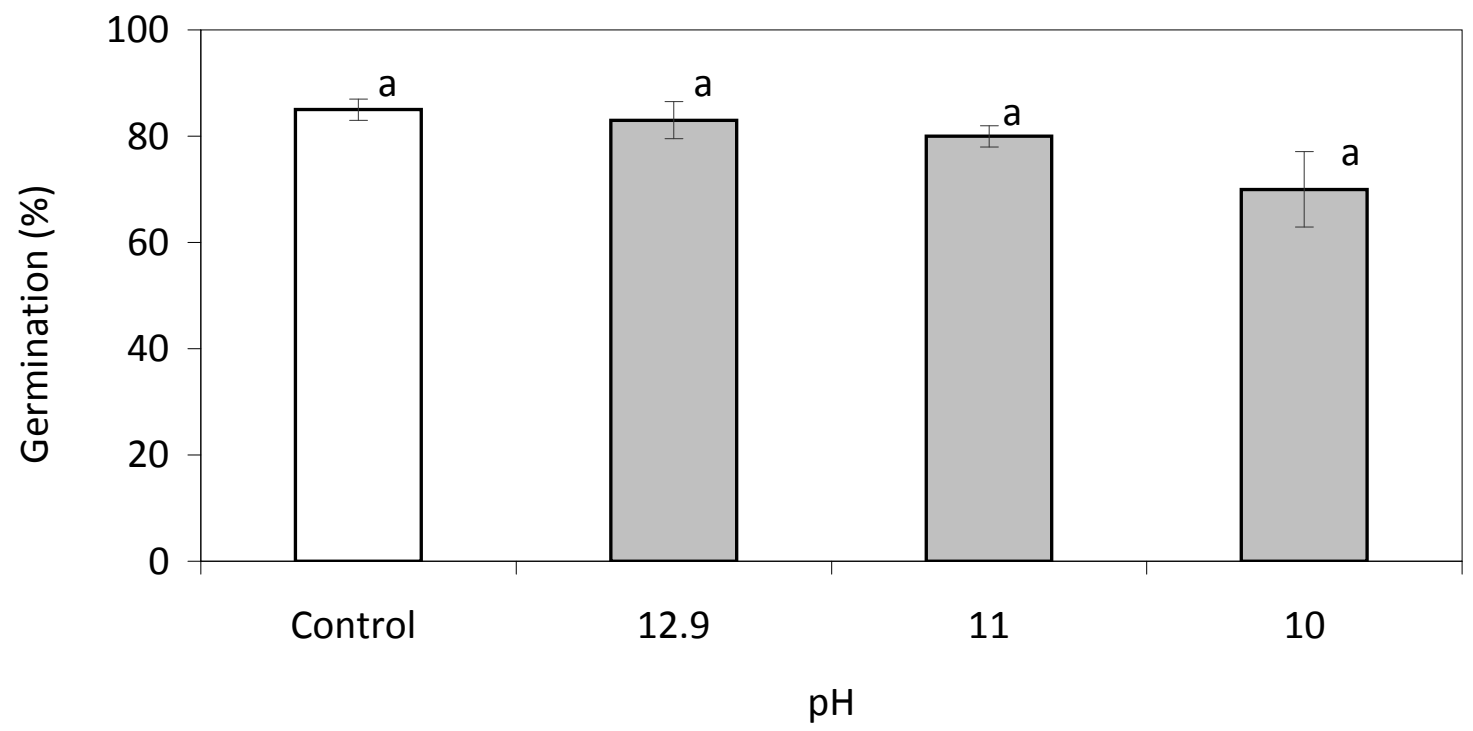

